\title{
FRESH AND HARDENED PROPERTIES OF LIGHTWEIGHT CONCRETE MADE WITH PUMICE AS COARSE AGGREGATE
}

\author{
*As' at Pujianto ${ }^{1}$ and Hakas Prayuda ${ }^{1}$ \\ ${ }^{1}$ Department of Civil Engineering, Faculty of Engineering, Universitas Muhammadiyah Yogyakarta, \\ INDONESIA
}

*Corresponding Author, Received: 15 Oct. 2021, Revised: 25 Oct. 2021, Accepted: 23 Nov. 2021

\begin{abstract}
The purpose of this research is to utilize pumice waste as one of the constituent materials of lightweight concrete. Indonesia, as an archipelagic country, has produced coral pumice waste scattered throughout the country. It is expected that by utilizing pumice waste, lightweight and environmentally friendly concrete may be produced. The tests carried out consisted of three series to examine the effect on the composition of light aggregate (series 1), the effect of light aggregate size (series 2), and the effect of the water to binder ratio (series 3). The composition of light aggregate as a substitute for coarse aggregate by $25 \%, 50 \%$, $75 \%$, and $100 \%$, with a maximum aggregate size of $20 \mathrm{~mm}$ and water to binder ratio of 0.50 . In the second series, the maximum size of lightweight aggregate is $9.5 \mathrm{~mm}, 16 \mathrm{~mm}, 20 \mathrm{~mm}$, and $25 \mathrm{~mm}$, using $100 \%$ lightweight aggregate with water to binder ratio of 0.50 . In the third series, the water to binder ratio is varied $0.46,0.48$, and 0.50 . A slump test was conducted to check the workability of fresh concrete, while the hardened properties test consisted of compressive strength and mass density. The results of the tests show that using a larger amount of lightweight aggregate reduces compressive strength. The variation of the maximum size of lightweight aggregate shows a pattern that the larger the aggregate size produces lower the compressive strength. The decrease in compressive strength also occurs in concrete with high water to binder ratio.
\end{abstract}

Keywords: Lightweight concrete, Pumice, Compressive strength, Mass density

\section{INTRODUCTION}

The construction industry is currently one of the biggest consumers in concrete production. Concrete remains the most popular construction material due to its many advantages, including durability, excellent resilience to various environmental conditions, and constituent materials widely available in many countries. The general ingredients of concrete consist of cement, water, fine aggregate, coarse aggregate, and superplasticizer. Several researchers predict that cement production will continue to increase until 2050, especially in developing countries such as India and China. It also concludes that concrete will continue to be a major consumption in the construction industry [1-4].

However, concrete also has several weaknesses, including low tensile strength and high mass density. The mass density of normal concrete is between $2300-2400 \mathrm{~kg} / \mathrm{m}^{3}$. The high mass of concrete is one of the issues that must be addressed in various structural scenarios, particularly for construction in earthquake-prone areas. The high mass density of concrete results in a high structural mass as well. If an earthquake occurs in a structure with a high mass density, the chance of damage due to gravity loads from the own concrete weight will be higher. Therefore, producing lightweight concrete is one of the right solutions in overcoming structural problems with high mass density.

Concrete is included in the lightweight category if the mass density produced is not more than 2200 $\mathrm{kg} / \mathrm{m}^{3}$. Currently, lightweight concrete applications have been carried out for both structural and nonstructural components, such as the use of lightweight concrete blocks [5-7], precast slab floor [8-10], and the precast lightweight concrete beam [11-13]. The lightweight concrete mixing process has been carried out in various ways, either by replacing cement with other pozzolanic materials or by changing the type of aggregate, both fine aggregate and coarse aggregate. The replacement of aggregates and cement has been widely carried out both with organic and inorganic materials. In addition, the use of various types of waste has also been found in the effort to produce lightweight concrete.

Several studies have been found in the manufacture of lightweight concrete, including corn cob and clay as coarse aggregate [14-16], fiber as lightweight materials [17-19], Palm Oil Waste (Shell and Clinker) [20-22], Plastic waste as coarse aggregate [23-25], and Styrofoam waste [26-28]. In addition, another material that is often used for the manufacture of lightweight concrete is to use pumice as a substitute for coarse aggregate. The pumice comes from various resources. Several studies have found in the manufacture of lightweight concrete using pumice, including 
volcanic pumice [29-31], Basaltic pumice [32-34], and Breccia pumice [35-37]. In this study, pumice was used from coral waste that was no longer used. There are not many studies that discuss the utilization of coral pumice as a coarse aggregate replacement for the manufacture of lightweight concrete.

This study aims to utilize coral waste that is no longer used as a construction material. The light characteristics of coral pumice can be used as aggregate for the manufacture of lightweight concrete. This research was conducted in Indonesia by utilizing coral pumice waste from Lombok Island. Because Indonesia is an archipelagic country with many corals, the utilization of coral remains is ideal, especially for construction in coastal areas. This research was conducted to examine the concrete properties using coral pumice as a constituent material. The slump test is carried out to check the concrete workability level at the fresh state. Meanwhile, the hardened properties are tested for compressive strength and mass density. Fresh and hardened properties tests were carried out with variations consisting of the percentage of coral pumice as a substitute for coarse aggregate, the maximum size of coral pumice, and different water to binder ratios.

\section{EXPERIMENTAL PROGRAM}

\subsection{Raw Materials}

The concrete constituent materials used in this study consisted of Portland pozzolan cement, fine aggregate, water, and coarse aggregate. Portland pozzolans cement used in this study refers to ASTM C595 [38] with a specific gravity of 3.15. Examination of fine aggregate is carried out to determine the mechanical and physical properties before being used as a concrete constituent material. Fine aggregate from the eruption of a volcano located in Yogyakarta, Indonesia. Water content, specific gravity, water absorption, unit weight, mud content, and grain grading are all tests for fine aggregate properties. The results of the fine aggregate test can be seen in Table 1, where the water content obtained is $2.53 \%$, the specific gravity is 2.66 , the water absorption is $10.11 \%$, the unit weight of the fine aggregate is $1.43 \mathrm{~g} / \mathrm{cm}^{3}$, while the mud content in the fine aggregate is $4.73 \%$. Particle size gradation of fine aggregate can be seen in Figure 1.

The coarse aggregate used in this study consisted of two types, namely normal aggregate and light aggregate (coral pumice). Table 2 shows the results of coarse aggregate properties. The tests consisted of water content, specific gravity, water absorption, mass density, roughness, and mud content. Based on the test results, it can be seen that there are some significant differences between the properties of normal aggregates and lightweight aggregates. The results of the water content test show that the lightweight aggregate contains high water, and the water absorption rate is also higher than the normal aggregate. In addition, the roughness content of the light aggregate is also higher than the normal aggregate. Based on the aggregate properties test, it can be seen that lightweight aggregate from coral pumice also has weaknesses that might cause the concrete performance to decrease.

In terms of light aggregate, it can be seen that the specific gravity produced is smaller than normal aggregate. This indicates that lightweight aggregate will be able to produce lighter concrete than normal concrete. This is supported by the results of the mass density test. The mass density test shows that pumice aggregate has a lower mass density than normal aggregate. Aggregate is one of the most important components of concrete, the produced lightweight concrete when the coarse aggregate used is probably light.

\section{Table 1 Properties of fine aggregate}

\begin{tabular}{lc}
\multicolumn{1}{c}{ Properties } & Results \\
\hline Water Content (\%) & 2.53 \\
Specific Gravity & 2.66 \\
Water Absorption (\%) & 10.11 \\
Mass Density (g/cm ${ }^{3}$ ) & 1.43 \\
Mud Content (\%) & 4.73 \\
\hline
\end{tabular}

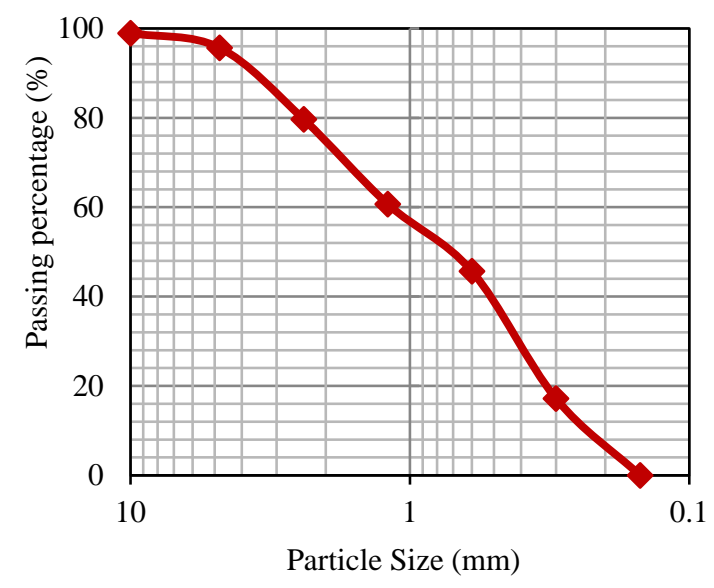

Fig.1 Size distribution of fine aggregates

Table 2 Properties of coarse aggregates

\begin{tabular}{lcc}
\multicolumn{1}{c}{ Properties } & $\begin{array}{c}\text { Normal } \\
\text { Aggregate }\end{array}$ & Pumice \\
\hline Water Content (\%) & 1.45 & 15.03 \\
Specific Gravity & 2.68 & 1.55 \\
Water Absorption (\%) & 1.45 & 11.54 \\
Mass Density (g/cm ${ }^{3}$ ) & 1.55 & 0.62 \\
Roughness (\%) & 23.54 & 36.51 \\
Mud Content (\%) & 0.67 & 0.93 \\
\hline
\end{tabular}




\subsection{Mix Proportion}

The investigation on the effectiveness of light aggregates in this study consisted of three main series. Variations made consist of the effect of substitution of light aggregate on coarse aggregate, the effect of the maximum size of light aggregate, and the effect of the water to binder ratio. The mix proportion series 1 consists of replacing aggregates with normal aggregates of 25\% (S1-25), 50\% (S150), $75 \%$ (S1-75), and $100 \%$ (S1-100). The maximum size of aggregate used in series 1 is 20 $\mathrm{mm}$ with water to binder ratio of 0.50 . Table 3 shows the material mix proportion for series 1 .

Series 2 in this study aims to determine the size effect of the coarse aggregate. The size of the coarse aggregate used has an impact on the compressive strength of concrete, particularly when specific aggregates are used as a substitute for normal aggregates. This series is composed out of $100 \%$ lightweight aggregate with aggregate sizes varying from $9.5 \mathrm{~mm}$ (S2-9.5), $16 \mathrm{~mm}$ (S2-16), $20 \mathrm{~mm}$ (S220), and $25 \mathrm{~mm}$ (S2-25) (S2-25). This series 2 also uses water to binder ratio of 0.50 . Table 4 shows the mix proportion for series 2. Meanwhile, this research also considers investigating the effect of the water to binder ratio. The investigation to determine the effect of the water to binder ratio consisted of three variations, namely 0.46 (S3-0.46), 0.48 (S43-0.48), and 0.50 (S3-0.50). Table 5 shows the results of the mix proportion for series 3 .

\subsection{Test Method}

The tests in this study were divided into two categories: fresh properties and hardened properties. Inspection of fresh properties is carried out using the slump test, which aims to determine the level of workability of fresh concrete. Meanwhile, hardened properties are carried out through mass density and compressive strength. A compressive strength test was carried out according to the ASTM C39 standard [39] with a cylindrical specimen height of $300 \mathrm{~mm}$ and a diameter of $150 \mathrm{~mm}$. The compressive strength test was carried out on the concrete, aged $3,7,14$, and 28 days with water curing. While the mass density test was only carried out on concrete with an age of 28 days.

Table 3 Mix proportion for series 1 in $1 \mathrm{~m}^{3}$

\begin{tabular}{lcccc}
\hline \multicolumn{1}{c}{ Materials } & $\mathrm{S} 1-25$ & $\mathrm{~S} 1-50$ & $\mathrm{~S} 1-75$ & $\mathrm{~S} 1-100$ \\
\hline Cement $\left(\mathrm{kg} / \mathrm{m}^{3}\right)$ & 409.70 & 409.70 & 409.70 & 409.70 \\
Water $\left(\mathrm{kg} / \mathrm{m}^{3}\right)$ & 204.85 & 204.85 & 204.85 & 204.85 \\
Coarse Aggregate (Normal) $\left(\mathrm{kg} / \mathrm{m}^{3}\right)$ & 607.19 & 404.79 & 202.39 & - \\
Coarse Aggregate $\left(\right.$ Pumice) $\left(\mathrm{kg} / \mathrm{m}^{3}\right)$ & 202.39 & 404.79 & 607.19 & 809.59 \\
Fine Aggregate $\left(\mathrm{kg} / \mathrm{m}^{3}\right)$ & 475.34 & 475.34 & 475.34 & 475.34 \\
Coarse Aggregate Size $(\mathrm{mm})$ & 20 & 20 & 20 & 20 \\
Water to Binder Ratio & 0.50 & 0.50 & 0.50 & 0.50 \\
\hline
\end{tabular}

Table 4 Mix proportion for series 2 in $1 \mathrm{~m}^{3}$

\begin{tabular}{lcccc}
\hline \multicolumn{1}{c}{ Materials } & S2-9.5 & S2-16 & S2-20 & S2-25 \\
\hline Cement $\left(\mathrm{kg} / \mathrm{m}^{3}\right)$ & 409.70 & 409.70 & 409.70 & 409.70 \\
Water $\left(\mathrm{kg} / \mathrm{m}^{3}\right)$ & 204.85 & 204.85 & 204.85 & 204.85 \\
Coarse Aggregate $\left(\right.$ Pumice) $\left(\mathrm{kg} / \mathrm{m}^{3}\right)$ & 809.59 & 809.59 & 809.59 & 809.59 \\
Fine Aggregate $\left(\mathrm{kg} / \mathrm{m}^{3}\right)$ & 475.34 & 475.34 & 475.34 & 475.34 \\
Coarse Aggregate Size $(\mathrm{mm})$ & 9.5 & 16 & 20 & 25 \\
Water to Binder Ratio & 0.50 & 0.50 & 0.50 & 0.50 \\
\hline
\end{tabular}

Table 5 Mix proportion for series 3 in $1 \mathrm{~m}^{3}$

\begin{tabular}{lccc}
\multicolumn{1}{c}{ Materials } & $\mathrm{S} 3-0.46$ & $\mathrm{~S} 3-0.48$ & $\mathrm{~S} 3-0.50$ \\
\hline Cement $\left(\mathrm{kg} / \mathrm{m}^{3}\right)$ & 409.70 & 409.70 & 409.70 \\
Water $\left(\mathrm{kg} / \mathrm{m}^{3}\right)$ & 188.46 & 196.66 & 204.85 \\
Coarse Aggregate (Normal) $\left(\mathrm{kg} / \mathrm{m}^{3}\right)$ & - & - & - \\
Coarse Aggregate $($ Pumice $)\left(\mathrm{kg} / \mathrm{m}^{3}\right)$ & 809.59 & 809.59 & 809.59 \\
Fine Aggregate $\left(\mathrm{kg} / \mathrm{m}^{3}\right)$ & 475.34 & 475.34 & 475.34 \\
Coarse Aggregate Size $(\mathrm{mm})$ & 20 & 20 & 20 \\
Water to Binder Ratio & 0.46 & 0.48 & 0.50 \\
\hline
\end{tabular}




\section{RESULTS AND DISCUSSION}

\subsection{Effect of Coral Pumice as Coarse Aggregate Replacement}

An investigation of the effect of lightweight aggregate composition on compressive strength was carried out in this study. Figure 2 shows the slump results on fresh concrete with variations of light aggregate as a substitute for coarse aggregate. A $25 \%$ replacement of light aggregate with coarse aggregate results in a slump of $190 \mathrm{~mm}$, whereas a $50 \%$ replacement of coarse aggregate with light aggregate results in a slump of $180 \mathrm{~mm}$. The $75 \%$ variation of light aggregate produces a slump value of $150 \mathrm{~mm}$, and at the use of $100 \%$ light aggregate, it produces a slump value of $135 \mathrm{~mm}$. Based on the inspection results, it can be concluded that the addition of the amount of pumice used results in a lower slump so that the workability of fresh concrete also decreases. This is due to the higher water absorption rate in pumice compared to normal aggregates. When the mixing process is carried out, the pumice aggregate can absorb water so that the workability of the concrete is also reduced.

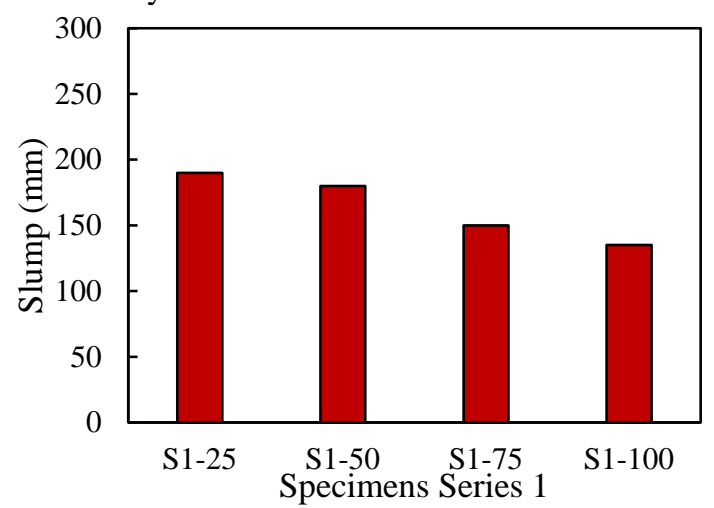

Fig.2 Slump results for lightweight concrete with different amounts of pumice aggregate

Figure 3 shows the compressive strength results at the age of $3,7,14$, and 28 days of concrete with variations of pumice as a substitute for coarse aggregate. Based on the variation of concrete ages, the compressive strength has increased for all specimens with increasing age of the concrete. The increase in compressive strength occurs due to the hydration process, and the level of hardening increases. Meanwhile, the test results show that the compressive strength has decreased as light aggregate composition increases as a substitute for coarse aggregate. The decrease in compressive strength is due to the increasing composition of lightweight aggregates. Aggregate roughness in Table 2 shows pumice has higher than normal aggregates. So that it can be concluded that lightweight aggregates are more brittle in resisting the compressive forces of normal aggregates

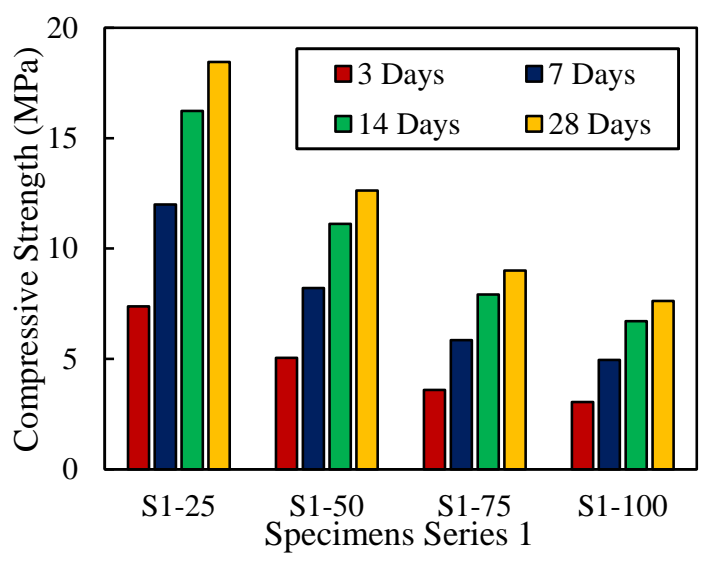

Fig.3 Compressive strength for lightweight concrete with different amounts of pumice aggregate

Figure 4 shows the mass density of concrete with variations in lightweight aggregate in concrete for 28 days. The test results show that as the amount of lightweight aggregate used increases, the mass density decreases. The decrease in the mass density of concrete occurs because the mass density of lightweight aggregate is lower than the normal aggregate. This test discovered that the concrete could no longer be classified as lightweight by replacing $25 \%$ of the coarse aggregate with lightweight aggregate. Lightweight concrete is defined with a coarse aggregate replacement of $50 \%$ to $100 \%$. In general, it can be concluded that the use of lightweight aggregates in large quantities will cause the workability of fresh concrete and the compressive strength of concrete to decrease. However, the mass density of concrete decreases, causing the concrete to become lighter.

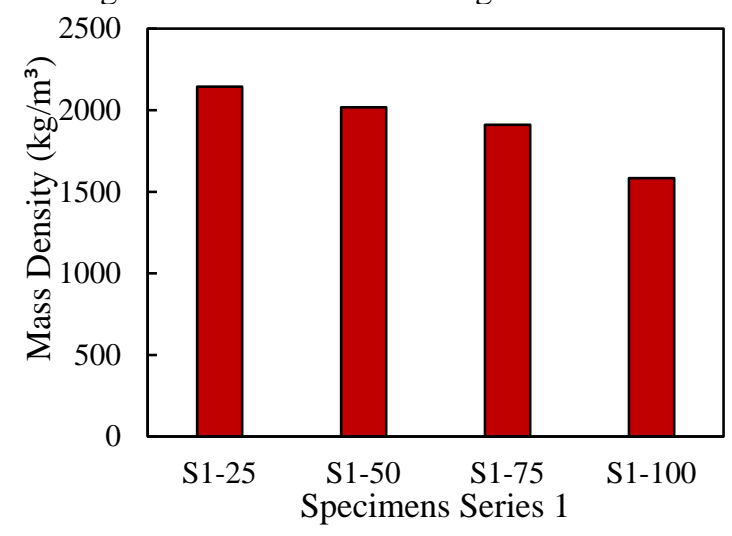

Fig.4 Mass density for lightweight concrete with different amounts of pumice aggregate

\subsection{Effect of Size of Coral Pumice}

The effect of maximum size of coarse aggregate on the fresh and hardened properties of concrete was also examined in this study. Figure 5 shows the results of testing fresh properties to determine the workability of concrete. The test results show that 
the resulting slump decreases as the maximum size of coarse aggregate increases. The decrease in workability is due to the increase in aggregate size, the ability of coarse aggregate to absorb water also increases because the aggregate surface will be wider.

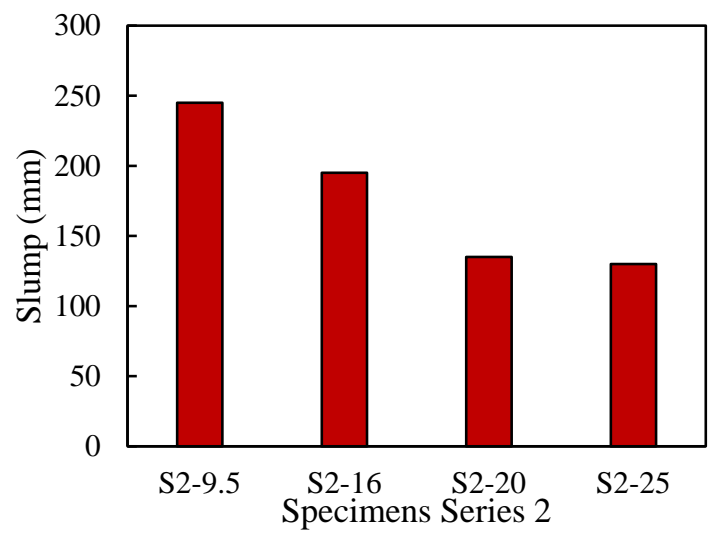

Fig.5 Slump results for lightweight concrete with different sizes of lightweight aggregate

The results of the compressive strength of concrete with variations in the maximum size of coarse aggregate can be seen in Figure 6. The test results show that as the size of the coarse aggregate increases, the compressive strength produced decreases. The larger size of the coarse aggregate causes the area of the aggregate in contact with the paste to be high. The surface of the pumice aggregate, which is smoother than normal aggregate will reduce the bonding between the paste and the aggregate. So, with a large aggregate size, the compressive strength will be lower compared to specimens with a smaller maximum size of coarse aggregate.

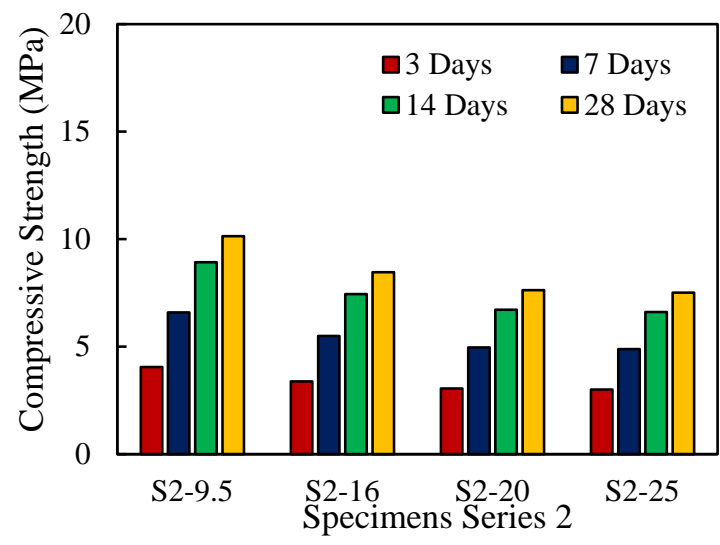

Fig.6 Compressive strength with different sizes of lightweight aggregate

Figure 7 shows the mass density of concrete at the age of 28 days with variations in the size of coarse aggregate. The investigation results show that with different aggregate sizes, the resulting mass density is almost the same. An insignificant difference in mass density due to the amount of aggregate used is the same even though the size is different.

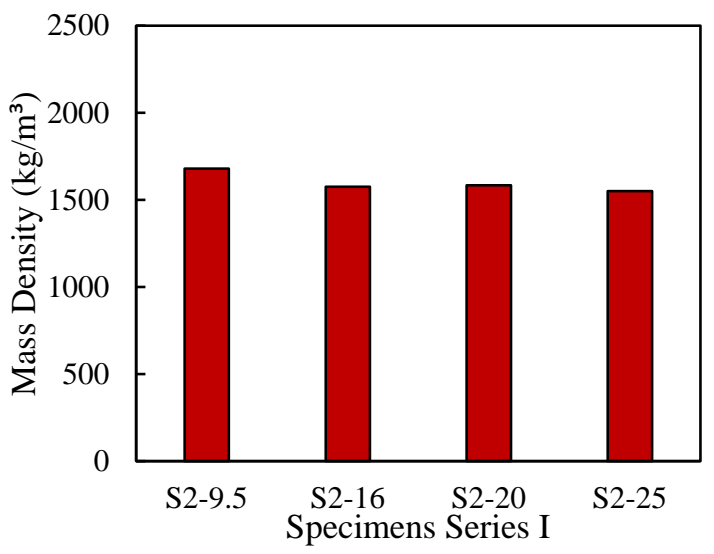

Fig.7 Mass density for lightweight concrete with different sizes of lightweight aggregate

\subsection{Effect of Water to Binder Ratio}

This study also carried out the effect of the water to binder ratio on the fresh and hardened properties of lightweight concrete. Figure 8 shows the results of the slump test with variations of water to binder ratio. The test results show that as the water to binder ratio increases, the slump value also increases. The increase in the slump value is caused by the increase in the amount of water used so that the fluidity level becomes high. The water to binder ratio of 0.46 produces a slump value of $90 \mathrm{~mm}$, while the water to binder ratio of 0.48 produces a slump value of $110 \mathrm{~mm}$, and using a water to binder ratio of 0.50 produces a slump value of $135 \mathrm{~mm}$.

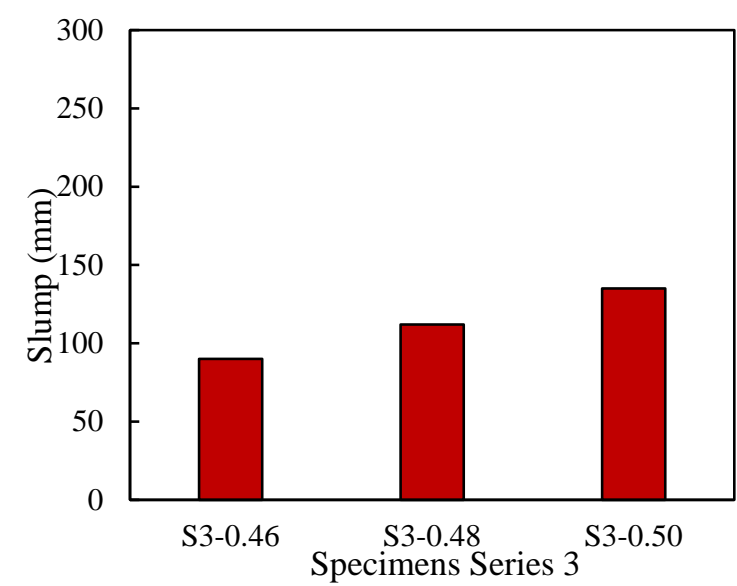

Fig.8 Slump results for lightweight concrete with different water to binder ratio

The results of the compressive strength of concrete with variations in the Water to binder ratio are shown in Figure 9. The test results show that as the water to binder ratio increases, the compressive strength produced decreases. The decreased compressive strength is due to the increased amount of water used when the water to binder ratio is high. 
Water that is not used by cement to react will evaporate during the hydration process. When the water has evaporated, it will leave pores which cause the compressive strength of the concrete to decrease. Therefore, the use of high water to binder ratio causes decreases in compressive strength of concrete, both at the initial age and in concrete with the age of 28 days.

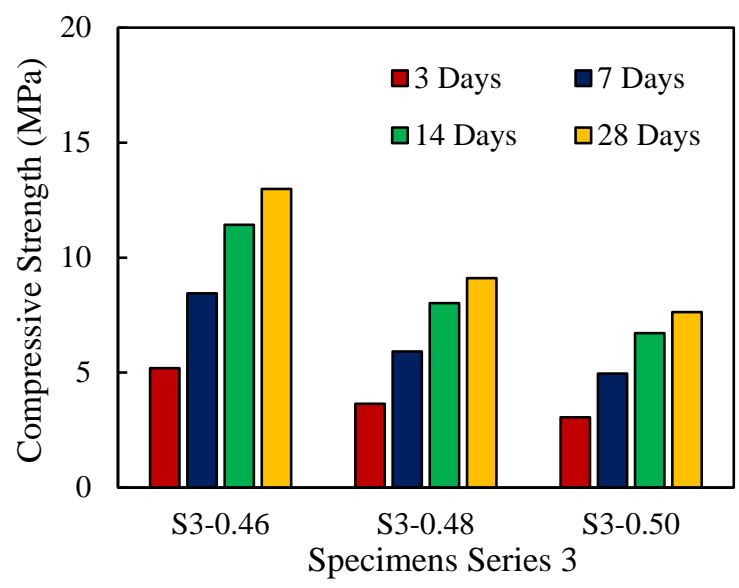

Fig.9 Compressive strength for lightweight concrete with different water to binder ratio

Figure 10 shows the mass density with variations of water to binder ratio in 28-day old concrete. The test results show that as the water to binder ratio increases, the mass density produced decreases. However, the reduction in mass density that occurs is not very significant between each variation. The reduction in mass density can be caused by increasing the number of pores in concrete with high water to binder ratio. The resulting pores cause the weight of the concrete to be reduced

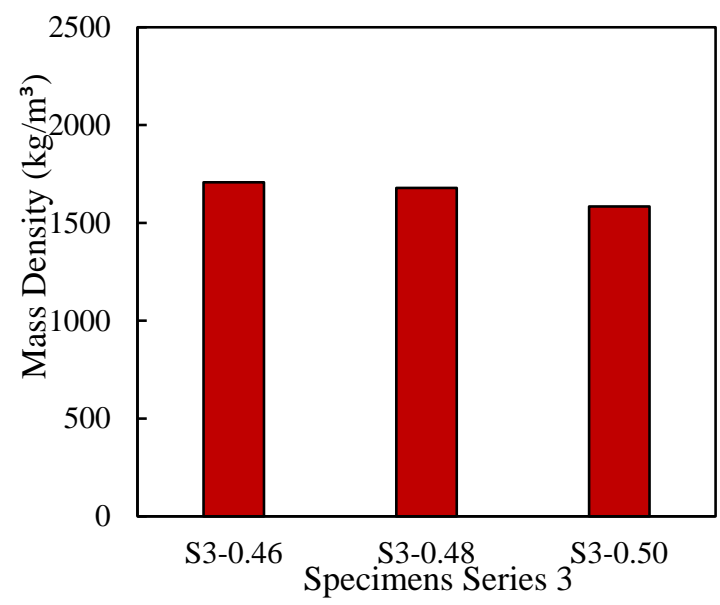

Fig.10 Mass density for lightweight concrete with different water to binder ratio

\section{CONCLUSION}

Based on the results and discussions that have been carried out, it can be concluded that: a. The addition of lightweight aggregate as a substitute for coarse aggregate causes workability, compressive strength, and mass density to decrease. The use of coral pumice aggregates of $50 \%$ to $100 \%$ can be categorized as lightweight concrete.

b. The maximum size of lightweight aggregate greatly affects concrete workability and compressive strength but does not affect the mass density.

c. High water to binder ratio results in a higher level of workability of the resulting concrete. However, the compressive strength of the concrete is reduced.

d. This lightweight aggregate utilization is not for structural components but can be used for nonstructural components to help reduce the load received by the structure.

\section{ACKNOWLEDGMENTS}

The authors would like to thank Deny Parwanto, Anggriani Giezela, and Hendrayanto Wibowo as research assistants on this project. The authors would also like to thank the structural and construction materials laboratory staff, department of Civil Engineering, Universitas Muhammadiyah Yogyakarta for assisting during the research process.

\section{REFERENCES}

[1] Imbabi M. S., Carrigan C., and McKenna S., Trends and Developments in Green Cement and Concrete Technology. International Journal of Sustainable Built Environment, Vol. 1, 2012, pp. 194-216.

[2] Schneider M., Romer M., Tschudin M., and Bolio H., Sustainable Cement Production Present and Future. Cement and Concrete Research, Vol. 21, 2011, pp. 642-650.

[3] Li N., Ma D., and Chen W., Projection of Cement Demand and Analysis of the Impacts of Carbon Tax on Cement Industry in China. Energy Procedia, Vol. 75, 2015, pp. 1766-1771.

[4] Andrew R. M., Global $\mathrm{CO}_{2}$ Emissions from Cement Production. Earth System Science Data, Vol. 10, 2018, pp. 195-217.

[5] Sutrisno., Putra R. R., and Ganefri., A Comparative Study on Structure in Building Using Different Partition Receiving Expense Earthquake. International Journal of Geomate, Vo. 13, Issue 37, 2017, pp. 34-39.

[6] Sari K. A. M., and Sani A. R. M., Applications of Foamed Lightweight Concrete. MATEC Web of Conferences, Vol. 97, 2017, pp. 1-5.

[7] Suttaphakdee P., Dulsang N., Lorwanishpaisarn N., Kasemsiri P., Posi P., and Chindaprasirt P., Optimizing Mix Proportion and Properties of 
Lightweight Concrete Incorporated Phase Change Materials Paraffin/Recycled Concrete Block Composite. Construction and Building Materials, Vol. 127, 2016, pp. 475-483.

[8] Suizi J., Wanlin C., Zibin L., Wei D., and Yingnan S., Experimental Study on a Prefabricated Lightweight Concrete Filled Steel Tubular Framework Composite Slab Structure Subjected to Reversed Cyclic Loading. Applied Sciences, Vol. 9, 2019, pp. 1-27.

[9] Yardim Y., Waleed A. M. T., Jaafar M. S., and Laseima S., AAC - Concrete Light Weight Precast Composite Floor Slab. Construction and Building Materials, Vol. 40, 2013, pp. 405-410.

[10] Rochman T., Rasidi N., Sumardi., Purnomo F., and Marjono., The Flexural Performance of Lightweight Foamed Precast Concrete Slabs: Experimental and Analysis. International Journal of Geomate, Vol. 20, issue 77, 2021, pp. 24-32.

[11] Vimonsatit V., Wahyuni A. S., and Nikraz H., Reinforced Concrete Beams with Lightweight Concrete Infill. Scientific Research and Essays, Vol. 7, Issue 27, 2012, pp. 2370-2379.

[12] Yip C. C., Marsono A. K., Wong J. Y., and Amran M. Y. H., Flexural Strength of Special Reinforced Lightweight Concrete Beam for Industrialized Building System (IBS). Jurnal Teknologi, Vol. 77, Issue 1, 2015, pp. 187-196.

[13] Gulec A., Kose M. M., and Gogus M. T., An Analysis of the Useability of Prefabricated Cage Reinforced Composite Beams with SelfCompacting and Lightweight Concrete Under Flexural Loads. Construction and Building Materials, Vol. 255, 2020, pp. 1-12.

[14] Nkayem D. E. N., Mbey J. A., Diffo B. B. K., Njopwouo D., Preliminary Study on the Use of Corn Con as Pore Forming Agent in Lightweight Clay Bricks: Physical and Mechanical Features. Journal of Building Engineering, Vol. 5, 2016, pp. 254-259.

[15] Faustino J., Silva E., Pinto J., Soares E., Cunha V. M. C. F., and Soares S., Lightweight Concrete Masonry Units Based on Processed Granulate of Corn Cob as Aggregate. Materiales de Construccion, Vol. 65, Issue 318, 2015, pp. $1-11$.

[16] Pinto J., Vieira B., Pereira H., Jacinto C., Vilela P., Paiva A., Pereira S., Cunha V. M. C. F., and Varum H., Corn Cob Lightweight Concrete for Non-Structural Applications. Construction and Building Materials, Vol. 34, 2012, pp. 346-351.

[17] Rasheed M. A., and Prakash S. S., Mechanical Behavior of Sustainable Hybrid-Synthetic Fiber Reinforced Cellular Lightweight Concrete for Structural Application of Masonry. Construction and Building Materials, Vol. 98, 2015, pp. 631-640.

[18] Asim M., Uddin G. M., Jamshaid H., Raza A.,
Tahir Z. R., Hussain U., Satti A. N., Hayat N., and Arafat S. M., Comparative Experimental Investigation of Natural Fibers Reinforced Light Weight Concrete as Thermally Efficient Building Materials. Journal of Building Engineering, Vol. 31, 2020, 1-11.

[19] Wijatmiko I., Wibowo A., and Nainggolan C. R., Strength Characteristics of Wasted Soft Drinks Can as Fiber Reinforcement in Lightweight Concrete. International Journal of Geomate, Vol. 17, Issue 60, 2019, pp. 31-36.

[20] Islam M. M. U., Mo K. H., Alengaram U. J., and Jumaat M. Z., Mechanical and Fresh Properties of Sustainable Oil Palm Shell Lightweight Concrete Incorporating Palm Oil Fuel Shell. Journal of Cleaner Production, Vol. 115, 2016, pp. 307-314.

[21] Muthusamy H., Mirza J., Zamri N. A., Hussin M. W., Majeed A. P. P. A., Kusbiantoro A., Budiea A. M. A., Properties of High Strength Palm Oil Clinker Lightweight Concrete Containing Palm Oil Fuel Ash in Tropical Climate. Construction and Building Materials, Vol. 199, 2019, pp. 163-177.

[22] Monika F., Prayuda H., Cahyati M. D., Syamsi M. I., and Purnomo A. D. R., The effect of Palm Shell as Coarse Aggregate Replacement on Self Compacting Concrete with Different Curing Methods. IOP Conference Series: Materials Science and Engineering, Vol. 1144, Issue 012022, 2021, pp. 1-9.

[23] Khalil W. I., Jaber A. A., and Abbas S. A., Mechanical Properties of Sustainable Concrete with Waste Plastic Bag. International Journal of Geomate, Vol. 19, Issue 75, 2020, pp. 144-150.

[24]Zaleska M., Pavlikova M., Pokorny J., Jankovsky O., Pavlik Z., and Cerny R., Structural Mechanical and Hygrothermal Properties of Lightweight Concrete Based on the Application of Waste Plastics. Construction and Building Materials, Vol. 180, 2018, pp. 111.

[25] Alqahtani F. K., Ghataora G., Khan M. I., and Dirar S., Novel Lightweight Concrete Containing Manufactures Plastic Aggregate. Construction and Building Materials, Vol. 148, 2017, pp. 286-397.

[26] Ismail Z. Z., Jaeel A. J., Alwared A. M., and Zavodska A., Experimental Investigation of a New Sustainable Approach for Recycling Waste Styrofoam Food Containers in Lightweight in Lightweight Concrete. Innovative Infrastructure Solutions, Vol. 6, Issue 110, 2021, pp. 1-8.

[27] Yasser., Parung H., Tjaronge M. W., and Djamaluddin R., Flexural Characteristics of Reinforced Concrete Beam Using Styrofoam Filled Concrete (SFC) in Tension Zone. International Journal of Engineering and Technology, Vol. 7, Issue 1, 2015, pp. 1-7. 
[28] Wulandari M., Compressive Stress-Strain Behavior of Concrete with Artificial Lightweight Aggregates and Steel fibers. IOP Conference Series: Materials Science and Engineering, Vol 1098, 2021, pp. 1-6.

[29] Madlangbayan M. S., Avendano J. M. M., Prodigalidad K. F., Peralta M. M., Almeda R. A., Peralta E. K., Sundo M. B., and Eneria M. A., Effect of Nano Silica on the Strength of Concrete with Volcanic Pumice as Coarse Aggregates. International Journal of Geomate, Vol. 19, Issue 75, 2020, pp. 50-57.

[30] Onoue K., Tamai H., and Suseno H., Shock Absorbing Capability of Lightweight Concrete Utilizing Volcanic Pumice Aggregate. Construction and Building Materials, Vo. 83, 2015, pp. 261-274.

[31] Hossain K. M. A., Ahmed S., and Lachemi M., Lightweight Concrete Incorporating Pumice Based Blended Cement and Aggregate: Mechanical and Durability Characteristics. Construction and Building Materials, Vol. 25, Issue 3, 2011, pp. 1186-1195.

[32] Yasar E., Atis, C. D., Kilic A., and Gulsen H., Strength Properties of Lightweight Concrete Made with Basaltic Pumice and Fly ash. Materials Letters, Vil. 57, Issue 15, 2003, pp. 2267-2270.

[33] Genon T., and Yazicioglu S., The Effect of Curing Conditions and Permeation of SelfCompacting Lightweight Concrete with Basaltic Pumice Aggregate. Arabian Journal for Science and Engineering, Vol. 43, 2018, pp. 5157-5164.

[34] Top S., and Vapur H., Effect of Basaltic Pumice Aggregate Addition on the Material
Properties of Fly Ash Based Lightweight Geopolymer Concrete. Journal of Molecular Structure, Vol. 1163, 2018, pp. 10-17.

[35] Widodo S., Satyarno I., and Tudjono S., Experimental Study on the Potential Use of Pumice Breccia as Coarse Aggregate in Structural Lightweight Concrete. International Journal of Sustainable Construction Engineering and Technology, Vol. 5, Issue 1, 2014, pp. 1-8.

[36] Widodo S., Satyarno I., and Tudjono S., Effects of Hybrid Polypropylene Steel Fiber Addition on Some Hardened Properties of Lightweight Concrete with Pumice Breccia Aggregate. International Scholarly Research Network in Civil Engineering, Vol. 2012, 2012, pp. 1-8.

[37] Widodo S., Ma’arif F., and Gen B. S., Thermal Conductivity and Compressive Strength of Lightweight Mortar Utilizing Pumice Breccia as Fine Aggregate. Procedia Engineering, Vol. 171, 2017, pp. 768-773.

[38] ASTM International, Cements C595/C595M20: Standard Specification for Blended Hydraulic”, American Standards Testing Materials, West Conshohocken, United States, 2020.

[39] ASTM International, C39/C39M-18: Standard Test Method for Compressive Strength of cylindrical Concrete Specimens, American Standards Testing Materials, West Conshohocken, United States, 2019.

Copyright (C) Int. J. of GEOMATE All rights reserved, including making copies unless permission is obtained from the copyright proprietors. 